\title{
Training in nutritional counseling: knowledge assessment and applicability in child's healthcare
}

\author{
Claudia Nery Teixeira Palombo 1 \\ Elizabeth Fujimori 2 \\ Áurea Tamami Minagawa Toriyama 3 \\ Luciane Simões Duarte 4
} 1-4 Departamento de Enfermagem em Saúde Coletiva. Escola de Enfermagem. Universidade de São Paulo. Av. Dr. Enéas de Carvalho Aguiar, 419. Cerqueira Cesar. São
Paulo, SP, Brasil. CEP: 05.403-000. E-mail: palombocnt@gmail.com

\begin{abstract}
Objectives: to assess the primary healthcare professionals'knowledge before and after the training in nutritional counseling and the applicability in child's healthcare.

Methods: a non-controlled 'before and after' intervention study, in a quantitative approach was conducted in Itupeva city in, São Paulo State. Training as an intervention was implemented for nurses, nursing assistants (NA) and community health agents (CHA), based on the critical-reflexive education. The professionals' knowledge was evaluated by applying a test with 16 multiple choice questions before and after the training. The nutritional counseling applicability in the services was evaluated by an open question test. The descriptive statistics and Fisher's Exact Test with significance of 5\% were used

Results: after training, the 'satisfactory' knowledge increased $71 \%$ in the nurses group and the NA/CHA groups. The professionals pointed out that training as an opportunity for qualification but the applicability lacks on political support and service organization.

Conclusions: training in nutritional counseling contributes to expand the primary care professionals' knowledge, although, the applicability in the routine depends on the efforts of local management and service organization.

Key words Professional training, Child's nutrition, Child's health, Public health nursing, Primary healthcare
\end{abstract}




\section{Introduction}

Inadequate dietary practices in the first years of life directly affect growth and development, increase infant morbidity and mortality rates, ${ }^{1}$ and there are strong evidences associated to the level of schooling and social inclusion in the adult life. 2

In Brazil, more than $50 \%$ of the children aged two to five years old present some type of food inadequacy $^{3}$ and also among children under the age of two. In a recent publication of the Inquérito Nacional de Saúde (National Health Survey) showed consumption of unhealthy food in more than $60 \%$ of the children consumed cookies, or cake and 32\% already consumed soft drinks. 4

Despite this, Brazil has received worldwide recognition for its success obtained in breastfeeding 5 but there are still indications for health professionals to require training to work in promoting maternal breastfeeding, including pediatricians, obstetricians and nurses. 6

The medical literature shows that professionals' training in nutritional counseling significantly improves maternal practice in child feeding, children's weight gaining and the professionals' performance and additionally increasing their knowledge. 7,8

In response to the recognition for the importance of healthy eating in promoting child's health, nutritional counseling techniques are inserted in several documents and governmental strategies intended for multi-professional teams, including community health agents to support the guidelines on healthy eating practices.9-11

Thus, understanding the need to advance in the adherence on the child's healthy feeding practices and assuming that professionals are properly qualified and can contribute more adequately to nutritional counseling, this present study aimed to assess the primary care professionals' knowledge before and after the training in nutritional counseling and the applicability in child's health.

\section{Methods}

A non-controlled 'before and after' intervention study, in a quantitative approach was conducted in Itupeva city in São Paulo State, with about 48,000 inhabitants.

As an intervention, training in nutritional counseling took place in September 2013 to February 2014, inviting all the primary healthcare professionals in the city. In order to allow everyone to participate, without any detriment in their services routine, four workshops were organized: one for nurses/physicians and three workshops for nursing assistants/technicians (NA)/community health agents (CHA), with a minimum workload of 16 hours each (two non-consecutive days).

Of the 83 health professionals who worked in the 12 basic units in the city (13 physicians, 12 nurses, $26 \mathrm{NA}$ and $32 \mathrm{CHA}$ ), 53 professionals (64\% of the total) effectively participated of the training: 11 nurses (92\%), 14 NA (54\%) and 28 CHA (88\%) No physicians participated.

The training was conducted for nurses and postgraduates in nursing. The Ministry of Health ${ }^{9-13}$ documents were used as technical basis and as pedagogical reference, the principles of criticalreflexive education was adopted in which learning is an integrated and qualitative process based on the dialogical-dialectic relationship between the educator and the student and promote elements for the subject to practice that learning can be really meaningful and to commit oneself in stimulating the reflection to transform in reality. 14

The implementation of training included workshops focused on communication and group interaction to create a space of affection, trust and respect. Considering the heterogeneity of the participants, regarding the training and the attributions in child's healthcare, the development of all the activities was based on previous knowledge on the topics addressed to the group and the pedagogical strategies included practical situations and service routines (Table 1).

In the beginning of the training, a structured questionnaire was applied to obtain information about sex (male/female), age (years), professional category (nurse, nursing assistants/technician, community health agent), how long they have been working in basic care (years), had training to work in basic care (yes/no), had training in child feeding (yes/no) the perception of their knowledge in nutritional counseling (excellent, good, reasonable and poor) and the use of nutritional counseling in the service routine (use a lot, use a little and do not use). The individual and unidentified professional knowledge test, applied before and after the training, replicated the test used by the Estratégia Nacional para Alimentação Complementar Saudável (ENPACS) (National Strategy for Healthy Complementary Food), with the inclusion of three pertinent questions to the content addressed (Caderneta de Saúde da Criança - Child Health Booklet- nutritional assessment and attitudes from the nutritional assessment) and the questions had different scores to assess the knowledge level. The 
Themes, objectives and pedagogical strategies used in the professionals' training in nutritional counseling. Itupeva, São Paulo, Brazil, 2013/2014.

\begin{tabular}{|c|c|c|}
\hline Themes & Objectives & Pedagogical strategies \\
\hline Child's Health Booklet (CHB) & $\begin{array}{l}\text { To reflect on the importance of } \mathrm{CHB} \text { as an } \\
\text { instrument for monitoring the child's } \\
\text { health. }\end{array}$ & $\begin{array}{l}\text { Displayed dialogue with discussion in } \\
\text { group and dramatization on the use of } \\
\text { CHB in the service routine. }\end{array}$ \\
\hline $\begin{array}{l}\text { Assessment on child's growth } \\
\text { and development (G/D) }\end{array}$ & $\begin{array}{l}\text { To reflect on the importance of G/D moni- } \\
\text { toring; } \\
\text { To recognize G/D as a biological process } \\
\text { and determining factors; } \\
\text { To evaluate the G/D; } \\
\text { To fill out and interpret G/D charts on the } \\
\text { CHB. }\end{array}$ & $\begin{array}{l}\text { Displayed dalogue with the use of CHB to } \\
\text { practice anthropometric measurements } \\
\text { and evaluate the milestones development; } \\
\text { Discussion of cases with intervention pre- } \\
\text { sentation through dramatization. }\end{array}$ \\
\hline $\begin{array}{l}\text { Most prevalent nutritional } \\
\text { disorders in childhood }\end{array}$ & $\begin{array}{l}\text { To reflect on nutritional transition in } \\
\text { child's health; } \\
\text { To know the determinants of the main } \\
\text { nutritional disorders, epidemiological } \\
\text { aspects, signs and symptoms, treatment } \\
\text { and interventions in the basic care. }\end{array}$ & $\begin{array}{l}\text { Discussion of each nutritional disorder in } \\
\text { subgroups and presentation in plenary; } \\
\text { Video presentation and discussion about } \\
\text { overweight children. }\end{array}$ \\
\hline Ten Steps for Healthy Eating & $\begin{array}{l}\text { To deepen the understanding of healthy } \\
\text { eating for children; } \\
\text { To reflect on the performance of health } \\
\text { professionals in promoting healthy eating. }\end{array}$ & $\begin{array}{l}\text { Collective construction of food groups; } \\
\text { Discussion of the case with dramatization } \\
\text { of the proposed intervention. }\end{array}$ \\
\hline Communication Techniques & $\begin{array}{l}\text { To develop communication skills for the } \\
\text { practice of nutritional counseling. }\end{array}$ & $\begin{array}{l}\text { Dialogue presentation, discussion of cases } \\
\text { with dramatization. }\end{array}$ \\
\hline
\end{tabular}

maximum score of the test was 30 points and the level of knowledge was classified as: unsatisfactory (0-10 points), reasonable (11-20 points) and satisfactory (21-30 points).

At the end of the training, the knowledge test was applied again and the participants were asked to respond in writing the open question: How do you evaluate the applicability of training in nutrition counseling in your professional practice? From the answers obtained, the frequency of the main themes was identified.

In the knowledge test, the data were processed in the Stata 13.1 software and the descriptive analysis was conducted separately for the group of nurses and the group of NA/CHA. Fisher's Exact Test was applied with a significance of $5 \%$ to classify the knowledge level.

This study was approved by the Research Ethics Committee under the document number: CAAE: 02081612.7.0000.5392. At the beginning of the training, after the explanation, the professionals signed a consent form.

\section{Results}

All the professionals who participated in the training were females with a mean age of 37.4 years old $(\mathrm{SD}=8.8)$ and the mean working time in the basic care was 4.5 years $(\mathrm{SD}=4.8)$. Most of the participants $(61.5 \%)$ received a training to work at the basic care (introductory course), but no one received a training in child feeding, except for maternal breastfeeding, referred by $19.2 \%$.

Regarding to the professionals' perception on their knowledge about nutritional counseling, 71.7\% of the participants considered their knowledge as "good" and $28.3 \%$ as "reasonable". As for nutritional counseling in the service routine, $55.8 \%$ of the professionals reported "use a lot", $42.3 \%$ reported "use a little" and $1.9 \%$ reported "do not use".

Table 2 shows the distribution of the number and percentage of the correct answers for each question in the knowledge test according to the group of professionals (nurses and NA/CHA) before and after the training, as well as the average number of correct answers and the minimum and maximum number. The percentage of correct answers was higher after training in most of the questions applied in both 
groups, with emphasis on the questions related to the attitudes after the nutritional assessment, the correct answer rate increased $61 \%$ for the group of nurses and $50 \%$ for the group of NA/CHA; the classification on nutritional status and communication techniques, which presented the same increase in the groups of nurses and NA/CHA; and the nutritional counseling techniques had an increase of $63 \%$ of correct answers and more than $30 \%$ in the groups of nurses and NA/CHA, respectively. The percentage of correct answers in the question that evaluated maternal breastfeeding was lower in the group of NA/CHA.

The knowledge test applied before and after the training showed an increase of 8.4 points in the average number of correct answers in the group of nurses and 7.8 in the group of NA/CHA, which tripled the minimum number of correct answers and doubled the maximum number after the training.
Regarding the classification of the knowledge level, Figure 1 shows the proportion of professionals with unsatisfactory, reasonable and satisfactory knowledge, before and after the training. There was a statistically significant increase of professionals with satisfactory knowledge after the training $(p<0.001)$, both in the group of nurses and in the group of NA/CHA.

After the training, $60.4 \% \quad(n=32)$ of the participants anonymously expressed their opinions in an open question test that evaluated their applicability in the professional practice. Of these, $92 \%$ answered that the content addressed could be applied in the service routine and $87 \%$ point out that training is an opportunity to be qualified and that it should be extended to all professional categories. The lack of political support and service organization so that changes could be effective, had negative aspects by $59 \%$ of the participants.

Table 2

Assessment of knowledge before and after the training in nutritional counseling by professional category. Itupeva, São Paulo, Brazil, 2013/2014.

\begin{tabular}{|c|c|c|c|c|c|c|c|c|c|}
\hline \multicolumn{2}{|c|}{ Theme of the questions } & \multicolumn{4}{|c|}{ Nurses* } & \multicolumn{4}{|c|}{$\mathrm{NA} / \mathrm{CHA} * *$} \\
\hline & & \multicolumn{2}{|c|}{ Before } & \multicolumn{2}{|c|}{ After } & \multicolumn{2}{|c|}{ Before } & \multicolumn{2}{|c|}{ After } \\
\hline & & $\mathrm{n}$ & $\%$ & $\mathrm{n}$ & $\%$ & $\mathrm{n}$ & $\%$ & $\mathrm{n}$ & $\%$ \\
\hline 1 & Use and filling out the Child's Health Booklet & 11 & 100.0 & 09 & 90.0 & 24 & 57.1 & 28 & 70.0 \\
\hline 2 & Baby's position for maternal breastfeeding & 08 & 72.7 & 08 & 80.0 & 20 & 47.6 & 24 & 60.0 \\
\hline 3 & Age to onset complementary feeding & 11 & 100.0 & 10 & 100.0 & 41 & 97.6 & 37 & 92.5 \\
\hline 4 & How to introduce other food & 10 & 90.1 & 09 & 90.0 & 31 & 73.8 & 35 & 87.5 \\
\hline 5 & Complementary feeding frequency & 01 & 9.1 & 07 & 70.0 & 20 & 47.6 & 30 & 75.0 \\
\hline 6 & Feeding schedules & 02 & 18.2 & 06 & 60.0 & 5 & 11.9 & 12 & 30.0 \\
\hline 7 & Food Consistency & 11 & 100.0 & 10 & 100.0 & 32 & 76.2 & 37 & 92.5 \\
\hline 8 & Food groups offered on baby food & 11 & 100.0 & 10 & 100.0 & 42 & 100.0 & 40 & 100.0 \\
\hline 9 & Offering fruit and vegetables & 10 & 90.9 & 10 & 100.0 & 37 & 88.1 & 40 & 100.0 \\
\hline 10 & Non-nutritional food consumption & 10 & 90.9 & 10 & 100.0 & 37 & 88.1 & 40 & 100.0 \\
\hline 11 & Hygiene care with food & 09 & 81.2 & 10 & 100.0 & 39 & 92.9 & 40 & 100.0 \\
\hline 12 & Food for sick child & 08 & 72.7 & 09 & 90.0 & 34 & 81.0 & 38 & 95.0 \\
\hline \multirow[t]{2}{*}{13} & Nutrition counseling technique: & & & & & & & & \\
\hline & guidance and support & 03 & 27.3 & 09 & 90.0 & 4 & 9.5 & 16 & 40.0 \\
\hline \multirow[t]{2}{*}{14} & Communication techniques to increase & & & & & & & & \\
\hline & mother's self-assurance & 05 & 45.5 & 09 & 90.0 & 11 & 26.2 & 29 & 72.5 \\
\hline 15 & Classification of nutritional status & 03 & 27.3 & 06 & 60.0 & 3 & 7.1 & 23 & 57.5 \\
\hline 16 & Attitudes after nutritional assessment & 01 & 9.1 & 07 & 70.0 & 4 & 9.5 & 24 & 60.0 \\
\hline \multicolumn{2}{|r|}{ Average on correct answers (standard deviation) } & 16.6 & 3.7 & 25.0 & 6.3 & 14.0 & 3.1 & 21.8 & 3.8 \\
\hline \multicolumn{2}{|c|}{ Minimum number of correct answers } & 10 & & 13 & & 8 & & 21 & \\
\hline \multicolumn{2}{|c|}{ Maximum number of correct answers } & 24 & & 30 & & 14 & & 28 & \\
\hline
\end{tabular}

*Nurses - Before: $n=11$; After: $n=10$

**Nursing assistants/technicians and Community Health Agents - Before: $n=42 ;$ After: $n=40$. 
Distribution of the proportion of professionals according to the classification of knowledge before and after the training in nutritional counseling. Itupeva, São Paulo, Brazil, 2013/2014.

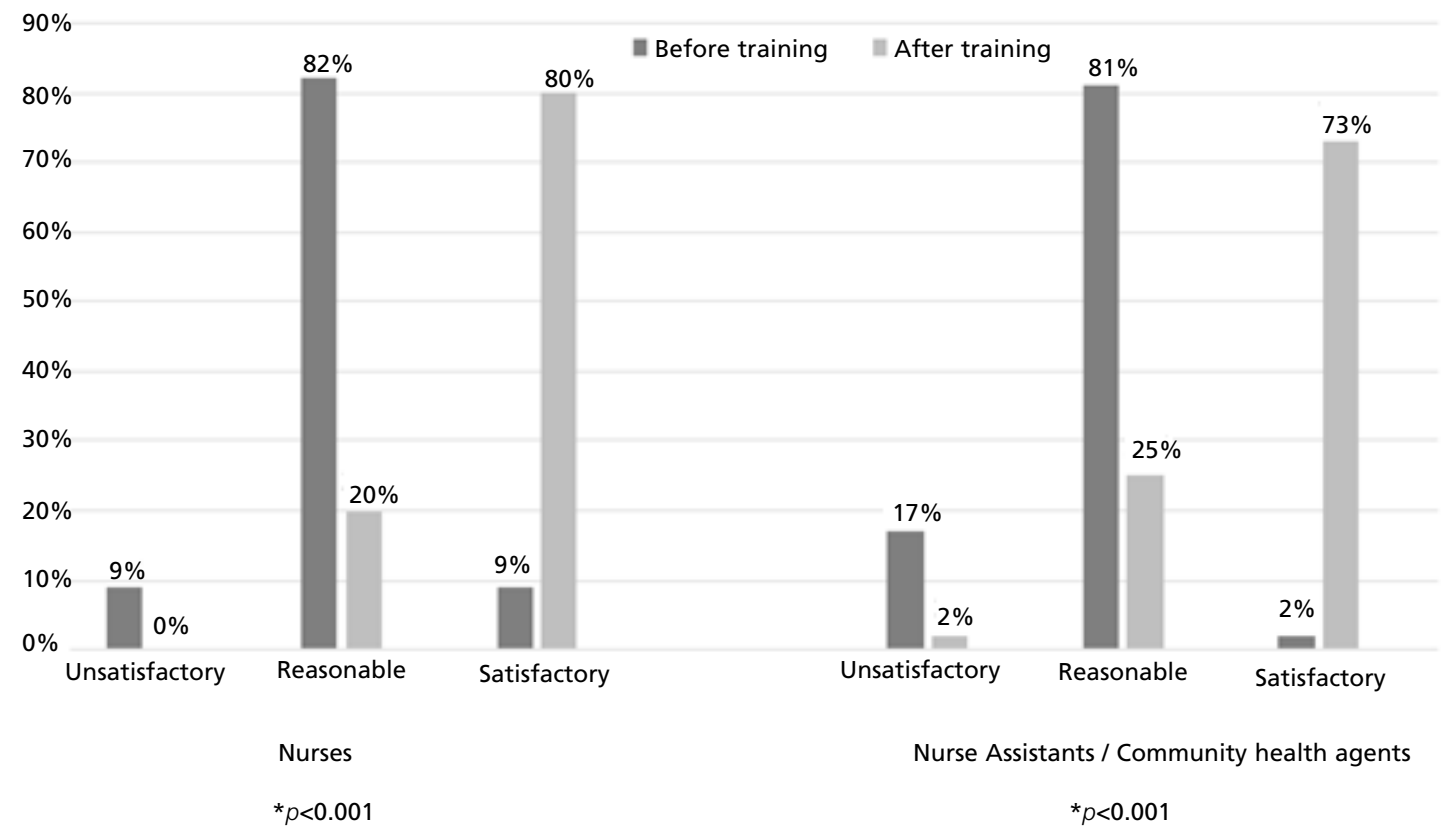

$N A=$ nursing assistants/technicians; $C H A=$ community health agents; (Nurses: before $n=11$, after $n=10 ; N A / C H A$ : before $=42$, after $n=40$ ). *Fisher's Exact Test.

\section{Discussion}

The training in nutritional counseling was conducted by two thirds of the primary care professionals from a small town, reiterated what is pointed out in the medical literature, when assessing health professionals' knowledge on before and after educational interventions on child feeding, positive results in the post -test are obtained. ${ }^{8}$

However, despite the significant increase in the proportion of professionals with "satisfactory" knowledge, it should be noted that prior to the training, there was a low proportion of correct answers regarding the classification of nutritional status and the attitudes after the nutritional assessment, not only in the group of NA/CHA, but also among the nurses, indicating deficit in knowledge in the interpretation of anthropometric indices and clinical nutritional management.

This result justifies the unfilled growth curves in the $\mathrm{CHH}$ in a study carried out in the same city, when only $9 \%$ of the growth charts were filled out by health professionals. 15 Growth and development monitoring are not a practice incorporated into child's healthcare, as recommended.16

Growth and development monitoring and the promotion of maternal breastfeeding and healthy complementary feeding are basic actions for integral assistance on child's healthcare since the 1980s and remains as a priority because it integrates the seven strategic axes list in the Política Nacional de Atenção Integral à Saúde da Criança (PNAISC). 17 (National Policy of Integral Child's healthcare)

However, there are still difficulties in the operation of this policy due to the lack of training and assistance protocols with underutilization of CHH. 18 The professionals also indicated problems of infrastructure of the service and maintenance of the hegemonic medical model in the city. 19

Before the training, nutritional counseling techniques and communication techniques presented a low percentage of correct answers. This result was a concern, as CHA are professionals that represent a nucleate element in 
health actions and should be able to establish dialogues with families and mediate the health team and the community with an accessible language. ${ }^{20}$ However, a study performed with CHA in two cities in Paraíba,in Brazil pointed out deficiencies related to child's healthcare guidelines, justifying professional depreciation and precarious working conditions. ${ }^{21}$

A low percentage of professionals scored "satisfactory" before the training, but it is worth to remember that although no professional had been trained before, most of the professionals considered their knowledge as "good", indicating that they overestimated their own knowledge. The same was true in Canada, where professionals did not consider the lack of knowledge and skills as a barrier to nutritional counseling, despite the lack of qualification on the topic and insufficient training. 22 Regarding maternal breastfeeding, less than half of the group of NA/CHA answered the question correctly on the evaluation of the baby's position to suckle. Even after the training, the percentage of correct answers did not even reach two-thirds. Poorer results were found in the South of the Country where only $8.2 \%$ and $18.6 \%$ of the primary healthcare professionals presented satisfactory performance in the knowledge and management scores on maternal breastfeeding, respectively. 23

Considering the broad investment in programs and actions to promote maternal breastfeeding in the Country with well-established training 6 a higher proportion of correct answers in this question was expected, as it was the only training mentioned by one- fifth of the participants.

The management of breastfeeding is still a major challenge for health professionals, who do not feel prepared to work with the aspects that involve the complexity of the act in breastfeeding. ${ }^{24}$ This points out to the necessity of continuous investment in the professionals' qualification in viewing to overcome threats to the successes already achieved in breastfeeding. 6

On the questions on complementary feeding, the percentage of correct answers was much higher in both phases, compared to maternal breastfeeding. Perhaps this result stems from the fact that we have assessed the knowledge on maternal breastfeeding with only one question.

Overall, the results showed that professionals had more theoretical knowledge about child feeding compared to the practice of clinical management on nutritional status and communication techniques which should be developed to support and encourage caregivers. 25 In addition, professionals present difficulties in applying nutritional counseling in the health service routines and do not recognize their role in providing this assistance. 19,25

Regarding the applicability of training in nutritional counseling, potentialities and difficulties were highlighted. The expansion of knowledge and the need for new and continuous qualification opportunities were pointed out as potentialities. In fact, professional training actions are essential to strengthen knowledge, practices and training for multidisciplinary teamwork. ${ }^{5}$ As for difficulties, the lack of political support and service organization and the need for the involvement of management professionals and others basic care professionals stand out the most. This result reiterates the strong influence that institutional, political, ideological and cultural conditions impose on the possibilities for transforming practices, 26 indicating that capacity represents only one part of the process and that changes in institutionalized practices require the involvement not only of professionals' service, but also those who decide and coordinate the policies. 27

Certainly, the absence of a medical team also interferes with the transformation of practices, considering the value of these professionals for the community and that the services are still centered on the biomedical model. ${ }^{19}$ Even in relation to maternal breastfeeding, the participation of medical professionals in qualification workshops is essential to maintain a successful framework, since pediatricians and obstetricians are widely trained to educate and provide effective support for breastfeeding women, they are also essential to promote breastfeeding practices in Brazil. 6

However, it is believed that training of practically all the nurses and CHA in the city, had an important increase in knowledge and will contribute to disseminate the contents they worked with, they are professional categories with specific surveillance attributions and health promotion that work with individual and collective educational actions at the homes and the community. 28

In this study, there was a limitation in the use of only one question to assess the applicability of the training, a qualitative study would contribute to enhance the understanding of subjective aspects. Another limitation was the non-identification of professionals in the knowledge test, an aspect that deserves attention, as it referred to the acquisition of knowledge assessment. As it is an intervention study, the results are useful for the health services and for the development of future studies, once the methodological approach has proved feasible and can be reproduced. 
The results showed that before the training, the professionals presented low knowledge about the nutritional classification and attitudes to be taken after the nutritional assessment, as well as deficits on knowledge in questions related to nutritional counseling and communication techniques. The training provided the professionals' knowledge an increase by representing the highest number of answers in practically all the questions applied on

\section{References}

1. Black RE, Victora CG, Walker SP, Bhutta ZA, Christian P, Onis M, Ezzati M, Grantham-McGregor S, Katz J, Martorell R, Uauy R, and the Maternal and Child Nutrition Study Group. Maternal and child undernutrition and overweight in low-income and middle-income countries. Lancet. 2013; 382 (9890): 427-51.

2. Victora CG, Horta BL, Mola CL, Quevedo L, Pinheiro RT, Gigante DP, Gonçalves H, Barros FC. Association between breastfeeding and intelligence, educational attainment, and income at 30 years of age: a prospective birth cohort study from Brazil. Lancet Glob Health. 2015; 3: e199-205.

3. Alves MN, Muniz LC, V MFA. Consumo alimentar entre crianças brasileiras de dois a cinco anos de idade: Pesquisa Nacional de Demografia e Saúde (PNDS), 2006. CiêncSaúde Coletiva. 2013; 18 (11): 3369-77.

4. Jaime PC, Frias PG, Monteiro HOC, Almeida PVB, Malta DC. Assistência em saúde e alimentação não saudável em crianças menores de dois anos: dados da Pesquisa Nacional de Saúde, Brasil, 2013. Rev Bras Saúde Matern Infant. 2016;16 (2): 159-67.

5. Rollins NC, Bhandari N, Hajeebhoy N, Horton S, Lutter CK, Martines JC,Piwoz EG, Richter LM, Victora CG Lancet Breastfeeding Series Group.Why invest, and what it will take to improve breastfeeding practices? Lancet. 2016; 387(10017): 491-504.

6. Pérez-Escamilla Rafael. Amamentação no Brasil: grande progresso, porém ainda há um longo caminho pela frente. J. Pediatr. (Rio J.). 2017;93(2):107-10.

7. Campos AAO, Cotta RMM, Oliveira JM, Santos AK, Araújo RMA. Aconselhamento nutricional de crianças menores de dois anos de idade: potencialidades e obstáculos como desafios estratégicos. Ciênc Saúde Coletiva. 2014; 19 (2): 529-38.

8. Sunguya BF, Poudel KC, Mlunde LB, Urassa DP, Yasuoka J, Jimba M. Nutrition training improves health workers' nutrition knowledge and competence to manage child undernutrition: a systematic review. Front Publ Health. 2013; 1 (37): 2-21.

9. Brasil. Ministério da Saúde. ENPACS: Estratégia Nacional Para Alimentação Complementar Saudável: Caderno do Tutor. Brasília, DF; 2010. 112p.

10. Brasil. Ministério da Saúde. Dez passos para uma alimentação saudável: guia alimentar para crianças menores de dois anos: um guia para o profissional da saúde na atenção básica. 2 ed. Brasília, DF; 2013. 75p.

11. Brasil. Ministério da Saúde. Alimentação saudável para the test. However, the applicability of training in nutritional counseling, from the perspective of Educação Permanente em Saúde (Permanent Health Education), depends on the effective involvement of the managers and the reorganization of services.

It reiterates the importance of the studies of this nature, with an evaluation of knowledge and applicability of the training, it is considered useful for health services and researches.

crianças menores de dois anos. Álbum seriado. Brasília, DF; 2011.

12. Brasil. Ministério da Saúde. Secretaria de Atenção à Saúde. Departamento de Atenção Básica. Saúde da Criança: crescimento e desenvolvimento (Caderno da Atenção Básica ${ }^{\circ}$ 33). Brasília, DF; 2012.

13. Brasil. Ministério da Saúde. Secretaria de Atenção à Saúde. Departamento de Ações Programáticas Estratégicas. Área temática de Saúde da Criança e Aleitamento Materno. Caderneta de Saúde da Criança: passaporte para a cidadania. Brasília, DF; 2013.

14. Freire P. Pedagogia da autonomia: saberes necessários à prática educativa. [internet]. Rio de Janeiro: Paz e Terra; 1997.

15. Palombo CNT, Duarte LS, Fujimori E, Toryiama ÁTM. Uso e preenchimento da caderneta de saúde da criança com foco no crescimento e desenvolvimento. RevEscEnferm USP. 2014;48 (nspe): 59-66.

16. Cursino EG, Fujimori E. Integralidade como uma dimensão das práticas de atenção à saúde da criança: uma revisão bibliográfica. RevEnferm UERJ. 2012; 20 (nesp1): 676-80.

17. Brasil. Ministério da Saúde. Portaria $N^{\circ} 1.130$ de 5 de agosto de 2015.Institui a Política Nacional de Atenção Integral à Saúde da Criança (PNAISC) no âmbito do Sistema Único de Saúde (SUS). 2015.

18. Pedrazza DF. Growth surveillance in the context of the Primary Public Healthcare Service Network in Brazil: literature review. RevBras Saúde Matern Infant. 2016; 16 (1): 7-19.

19. Palombo CNT, Fujimori E, Toriyama ATM, Duarte LS, Borges ALV. Difficulties in nutritional counseling and child growth follow-up: from a professional perspective. RevBrasEnferm. 2017; 70 (5): 949-57.

20. Maciazeki-Gomes RC, Souza CD, Baggio L, Wachs F. O trabalho do agente comunitário de saúde na perspectiva da educação popular em saúde: possibilidades e desafios. CiêncSaúde Coletiva. 2016;21(5):1637-46.

21. Pedraza DF, Rocha ACD, Sales MC. O trabalho educativo do agente comunitário de saúde nas visitas domiciliares em dois municípios do Brasil.TrabEduc Saúde. 2016; 14 (suppl. 1): 105-17.

22. Wynn K, Trudeau JD, Tauton K, Gowans M. Nutrition in primary care: current pratices, attitudes and barriers. CanFamPhys. 2010; 56: e109-16.

23. Vasquez Jamila, Dumith Samuel C., SusinLulie Rosane Odeh. Aleitamento materno: estudo comparativo sobre o 
conhecimento e o manejo dos profissionais da Estratégia Saúde da Família e do Modelo Tradicional. RevBras Saúde Matern Infant. 2015; 15(2): 181-92.

24. Almeida JM, Luz SAB, Ued FV. Support of breastfeeding by health professionals: integrative review of the literature. Rev Paul Pediatr. 2015; 33 (3): 355-62.

25. Chaturvedi A, Nakkeeran N, Doshi M, Patel R, Bhagwat S. Capacity of Frontline ICDS: Functionaries to Support Caregivers on Infant and Young Child Feeding (IYCF). Practices in Gujarat, India. Asia Pac J Clin Nutr. 2014; 23 (Supl. 1): s29-s37.

26. Davini MC. Enfoques, Problemas e Perspectivas na Educação Permanente dos Recursos Humanos de Saúde. In: Brasil. Ministério da Saúde. Secretaria de Gestão do Trabalho e da Educação na Saúde. Departamento de Gestão da Educação em Saúde. Política Nacional de Educação Permanente em Saúde. Brasília, DF: Ministério da Saúde; 2009.

Received on April 17, 2017

Final version presented on September 13, 2017

Approved on December 8, 2017
27. Brasil. Ministério da Saúde. Secretaria de Gestão do Trabalho e da Educação na Saúde. Departamento de Gestão da Educação em Saúde. Política Nacional de Educação Permanente em Saúde. Brasília, DF: Ministério da Saúde; 2009.

28. Roecker S, Nunes EFPA, Marcon SS. The educational work of nurses in the Family Health Strategy. Texto Contexto Enferm. 2013; 22 (1): 157-65. 